\title{
Eppur si muove
}

James D. Fry, Bryane Michael, and Natasha Pushkarna - 9781526152428 Downloaded from manchesterhive.com at 04/26/2023 01:54:30PM 
James D. Fry, Bryane Michael, and Natasha Pushkarna - 9781526152428 Downloaded from manchesterhive.com at 04/26/2023 01:54:30PM 